\title{
CD244 Gene
}

National Cancer Institute

\section{Source}

National Cancer Institute. CD244 Gene. NCI Thesaurus. Code C104068.

This gene plays a role in leukocyte activation and immune function. 